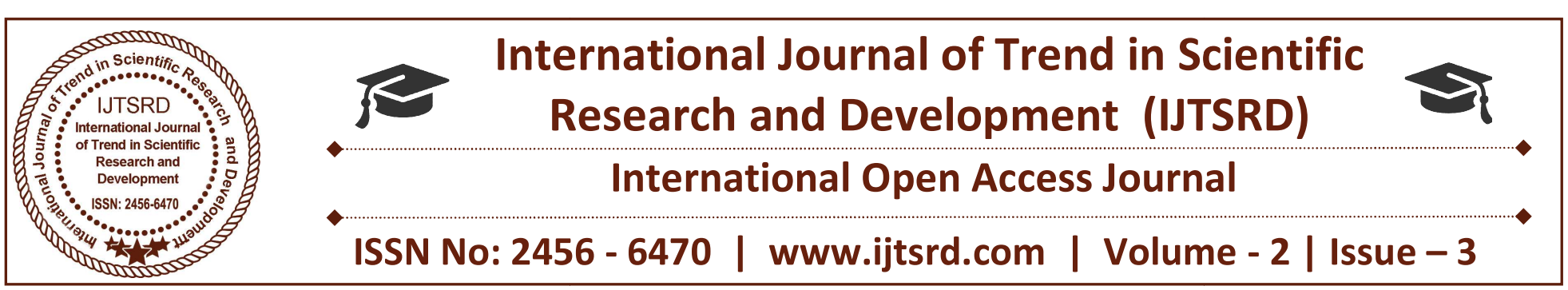

\title{
Development Project Affect the Environment of Assam
}

\author{
Mohon Rongphar \\ M. Phil, Assam University Diphu Campus, \\ Diphu, Karbi Anglong, Assam, India
}

\section{ABSTRACT}

There is little bit of environmental knowledge which the students of Political Science have not studied in earlier time, but after 1970s, environmentalism became an important dimension of it. In the contemporary Political theory, the issue of environment, gender, political ecology, green politics, eco-feminism, development and multiculturalism issues have come up in recent times. Therefore, the nature and scope of Political Science is widened. The reason is that issues of environment and natural resources have become one of the new emerging aspects of politics today. Environmental protection in India is involves by the local poor people, activists and disadvantages masses that have been directly affected the ecological environment. None of the academic researcher and protesters was undertaken on the construction of large Dams in the seismic active region of Assam and elsewhere in the Northeast India. The projects which have been affected the livelihood of the local people and even floods. The earnest concern of marginalisation by the tribal people of India and north east which has affected the life and livelihoods of the dam region. Many tribal people of the Northeast affect due to environment destruction because their cultural materials are associated with it. Now with the coming of industries and semi-urban in the ecosystem region all the functional system of the ecosystem sites has been decreasing day by day. The paper tries to focus on the seismic active region and violation of environmental laws of Assam. This paper aim that development project (dam) affect the environment of Assam. The paper also focuses on the marginalisation of the tribal people of Assam.

Keywords: Ecosystem destruction, Seismic active, Socio-cultural Marginalisation

\section{Introduction:}

Environmental issue constitutes an important dimension of Political Science both from an academic and practical point of view. The issue has been increasingly attracting the attention of academicians, researchers and policy makers for its obvious role in national and global politics. The ecology and environment issues which include river disputes, construction of dams, deforestation, soil erosion, pollution, environmental degradation, ozone depletion, melting of mountains resulting in the inundation of coastal areas has influenced the public policy at the domestic circles as well as the politics at the global level. Environment has been on the political agenda since the late 1960s. In Political Science the issue of environmentalism was not very much present in earlier time, but after 1970s, the study of environmentalism became an important dimension of it. One distinguishing characteristic is that it has a primary concern with the relationship between human society and the natural world. This human-nature relationship connects the extraordinarily diverse set of issues encompassed by environmental politics, which include wilderness preservation and nature conservation, air, water and land pollution, the depletion of scarce resources such as fish stocks, rainforests and endangered species, the use of nuclear power and biotechnology, and 'global' problems such as biodiversity loss, climate change and ozone depletion. Assam is on the brink of a movement like the one that ended with the 1984 Assam Accord. This time the concern is not illegal immigrants but dams proposed upstream in Arunachal Pradesh. In the past year half of the people in Assam have held a number of protests including the activists, students and political leaders on large dam 
particularly a mega hydro project under construction on the Subansiri River existed in the earthquake seismic active region. The 2, $000 \mathrm{MW}$ Subansiri Lower Project is the biggest dam existed in the Gerukamukh of Assam-Arunachal border.

\section{Objective of the Paper:}

The objective of the paper are given below-

a. To study large dam exist in the seismic prone zone.

b. To access the downstream people of Assam dissatisfactory.

c. To examine the Environmental Issue and Environmental Laws violation in Assam.

d. To Study the Social and Cultural Marginalisation from the dam area of Assam.

\section{Methodology:}

Information was collected through less in primary and more on secondary sources. On the basis of Subansiri dam primary method is conducted by focused group to various local organisations and interview method. The data are collected from published research paper, report, journal, books, internet, e-book, and expert as well as government report etc. While Karbi Langpi and Kopili projects of Assam is conducted through secondary data as usual. Projects have affected the local people after the dam completion. The present paper is primarily focused on to know about the significance of how development affects environment and the livelihoods of the downstream areas of Assam. The tribal people have a deep impact and much associated with the surrounding forest and dam development perspective. Collection of data is based on secondary source as the main methodology for this paper. Various data would be analysed for the discussion of the paper.

\section{Result and Discussion:}

\section{A. Large Dam in the Seismic Prone Zone:}

The Seismic zone of Himalayas region is referred to "as the Very High Damage Risk Zone". This led to the formation of Himalayan mountain range which extent from Kashmir to entire northeast India and the present day seismicity in this region is "due to the continuous collision between Indian and Eurasian plates" making it is classed as one of the most seismically active zone-' $\mathrm{V}$ ' most dangerous prepared by the Indian seismologists (Taher\&Ahmed, 2007: 21). The high Mountainous region in the foothills of Arunachal-Assam border that large dam is yet to be completed which is located in the rich biodiversity hotspot region, ecologically sensitive and prone to earthquakes. Among the local inhabitants the benefits of the projects has not shared with them though they were subjected to major threats to people livelihoods, environment and culture. This has provoked controversy and is a potential of future conflict in the state. Several large earthquakes with magnitude above7.0 occurred in this region during the last hundred years.

One of the main grounds of opposition to construction of large dams is located in the high seismicity region that has damage the ecosystem is one the major root cause of Assam. An organized campaign by environmental groups supported by International organisations against taking up large scale development projects. Environmentalists' view that safety of such mega-dams, in event of occurrence of large earthquakes cannot be ensured. To stress their point and raise public scare, doomsday scenarios are being projected of dam failures during earthquakes. The earthquake engineer's experts and dam designers have consulted for construction of large dam in the seismic active zone with the application of the modern technology; therefore, it is possible to build safe structure in seismically active regions'. However, a clear-cut appreciation of true facts in this regard seems taking at policy making levels in the government (Jatana, 1999: 1\&2). The power projects in northeast region include Dibang, Kameng, Subansiri, Ranganadi, Umtru, etc. which existed in the earthquakes as well as the floods prone zone and the Karbi-Langpi, Kopili and Kurichu etc. has been raising concerns about dam-induced floods in the downstream areas of Assam. Dams and reservoirs being the biggest man-made structures have special targets for their criticism and opposition. Proposals for new major projects in Himalayan terrain including the Northeast are haunted by questions of damage to environment, ecology on account of seismicity, geology, flora and fauna, etc. There is no consensus amongst the seismologists about the level of seismicity along various segments of Himalayan arc, origin of the earthquakes, concentrations of seismic activity of future earthquakes. While the Karbi Langpi and Kopili the two projects of Karbi Anglong district 
is existed in the ecosystem and in the hill areas which has affected the forest region.

\section{B. Downstream Assam Dissatisfactory:}

The Northeastern region was unexplored for a various factors, such as the inhospitable environmental condition, poor grid transmission system, lack of investment in hydro electricity sector, poor accessibility, and low demand of power in this region. Large power potential of the region would be the sound contribution to the national economy. The North- Eastern States (including Sikkim) has the potentiality to be the 'Power House of India'. This region has one of the biggest water wealth of the world. Generating the hydro-power it could enhance economic growth of the region and take an important role in country's development. To achieve the Vision 2020 , it is very important to complete these propose projects of the region and transmit the power to others power regions of the country. After competition of these projects the entire economy could be changed. There are several factors which should be kept in mind for proper sustainable development of hydro projects (Das, 2013: 38-3942\&43). Assam th considered as the corridor for northeast economic and industrial development which has contributes for the country's development. With the construction dams in the north east region and Assam got much disturb or pollute the river due to huge dam's construction in the upstream areas. Water flow downstream will be regulated by the dam which is expected to result in low release during winter and very high releases when energy is being generated. While in the Karbi Langpi and Kopili dam the downstream people suffers from ground water and floods annually.

\section{Environmental Issue:}

An Environment Impact Assessment study was conducted to understand the impact of the power project on various facets of environment in the downstream of Subansiri River. This report that the National Hydro Power Corporation got the clearance from the Ministry of Environment and Forest, Government of India possessed many loopholes in respect to the downstream. It becomes evident that no sufficient and detailed study was done in the entire downstream during the preparation of the report. Detailed mentioned about the probable impacts upon the downstream river health, rare and endangered species, physical resource, people's livelihood and the options for mitigation etc. did not find place in the report. However, the total downstream flood plain of the river Subansiri from the dam site to its confluence with the mighty river Brahmaputra is approximately $130 \mathrm{~km}$ which are suitable for aquatic organisms. Interestingly no report on the IUCN red listed Ganges Dolphin Platanista gangetic Roxb has been made in the report but in the present day the river affects the habitat aquatic animal. Due to large dam in the Subansiri River such important of native fish and aquatic animal will extinct because such species have no more to migrate in the downstream Assam (Dutta \& Sarma, 2012: 2955 \& 2956). At Kopili and Karbi Langpi dam the Department of forest for plantation has not been initiated till date.

\section{Environmental Laws Violation:}

Due to Subansiri large dam construction there is great destruction of the biological diversity in the Subansiri forest region. For dam development of the Subansiri River the ecosystem had damaged along with polluting fresh water sources. Since 2001, the government has given permission to conduct survey and investigations; NHPC has repeatedly committed serious violations of both the Forest (Conservation) Act, (1980) and the Environment Impact Assessment notification in 1994. In particular, the Dulung and Subansiri Reserved Forests at Lakhimpur and Dhemaji district of Assam has been identified as the 'Subansiri Important Bird Area (SIBA)' as per international criteria of Birdlife International and home to huge species of birds only several species had been listed possibly. The deficiencies in the Impact Assessment studies highlighted by a special team from the Indian Board for Wildlife renamed as National Board for Wildlife. In a Seminar presentation regarding the Lower Subansiri project at the international conference in 'Portugal', Hydro 2004, and NHPC made several tall claims about their commitments for wildlife protection in the Lower Subansiri project.

As back as in 1879 an Act named as Elephant Conservation was passed to restrict indiscriminate catching of elephants. Similarly, Wild Bird Conservation Act was adopted in 1887 and Forest Conservation Act was adopted in1891 (Taher \& Ahmed, 2007: 73). Some of the important key guidelines for eco-sensitive zones around National Parks and Wildlife Sanctuary, in the protected and reserve forests of Assam with reference to Ecosensitive region had several grounds: 
To protect the state concern forest the government of India proposes the Act and policies to conserve the eco-sensitive zones in the 'notified area' and the rights to participate the local people with the application of indigenous knowledge. Conservation and preservation is necessary in the deep forest resources but 'indiscriminate felling of trees' and 'killing of Wild animals' have been made by government restricted and need to conserve these resource declaring some forest areas as 'reserve forest', some as Wild Life Sanctuaries and some as National Parks.

$>$ The National Wildlife Action Plan (NWAP) 20022016, by the Indian Board for Wildlife held on $21^{\text {st }}$ January 2002, stated that "Areas outside the protected area network are often vital ecological corridor links and must be protected to prevent isolation of fragments of biodiversity which will not survive in the long run. Land and water use policies will need to accept the imperative of strictly protecting ecologically fragile habitats and regulating use elsewhere".

The purpose of declaring Eco-sensitive zones around National Parks and Sanctuaries is to create some kind of "Shock Absorber" for the Protected Areas. They would act as a transition zone from high to lesser protection areas. As has been decided by the National Board for Wildlife, the activities in the Eco-sensitive zones would be a regulatory nature rather than prohibitive nature, unless and otherwise so required (www. Forest.bih.nic.in: p-3\&5).

However, violations include extensive collection of boulders, stone, gravel, sand and earth from the riverbed, massive construction activities for project housing and construction of roads on the left bank of river, planting of gravel crusher adjacent to the river, barrier of an elephant corridor with fencing in the Subansiri Reserve Forest, dumping of muck and debris in the river etc. (Dutta \& Sarma, 2012: 2956). Especially in Assam there is huge site of Ecosensitive zone or Ecosystem region where dam projects have been constructing or constructed. The structure of biological sites in the state of Assam has been destructing as well as damaging day by day. This reason which has been result global warming and climate change.

\section{E. Relation Between Environment and Development:}

A Few relationships between development and the environmental can be characterised as one of interdependence. Just as development is impossible without a good condition of living environment so quality environment cannot be maintained in habituated or intensively exploited areas without their sustainable development.

The impact of development on environment is determined specifically of two factors - (a) Approach to development that means, if we consider development narrowly only as economic growth the quality of environment in general is not quite as important as abundance, quality and accessibility of natural resources of raw materials and energy central for the economy. If we understand development more broadly, in the sense of sustainable development the quality of environment and its sustainable condition will become one of key priorities. In such case, long term preservation of environment's inhabitability or eventually the betterment of its condition will be at the centre of attention.

The impact of living environment on developmentthat environment is one of the important decisive factors exerting influence on development possibilities. It is empirically known that diversified strategies of development must be applied in urbanised, industrial and rural areas. Different method of development must be chosen in the concern areas, different ones are valid in mountains and in lowland or highlands. Type of ecosystem and climate change of the area where we want to implement a development programme also play an important role. Among the most decisive factors rank includes climate zone (tropical, subtropical, temperate zone); basic physical-geographical factors (e.g., elevation above sea-level, rainfall, temperatures); the living environment quality (e'g., the degree of pollution, population density, expanse of deforested areas, the level of soil degradation and desertification); the quality and fertility of soil; the quality and quantity of natural resources of raw materials and energy. Accessibility of sustainable resources includes drinking water resource, consumption of forest products and the like (Euromodel - Environment \& Development, p-7\&8). When development is taken place on the earth environment somehow affect or harm directly or indirectly because any development sector will be happened on the earth only. Because 
technology had reached, without physics a country could not control or run the on this earth therefore, with the application of new technology environment got affected directly.

\section{F. Development affects Environment:}

Environmental impacts can discuss above the land use change is arguably the most pervasive socioeconomic force driving changes and degradation of ecosystems. For example, it has long been recognised that agricultural land use and practices can cause water pollution and the effect is influenced by government policies.

Development affects the environment that developments ameliorate climate change. It is almost done at the expense of natural ecosystems such as forestlands or wetlands which are carbon sinks that absorb carbon dioxide. For example, trees are 50 percent of carbon. When forests are cleared for agriculture or urban development like dam construction, road construction in the deep forests areas, they are often just being burned down or cut down. Even when forest is turned into timber for construction, the wood will eventually be decomposed by microorganism and carbon-dioxide is released. This how deforestation ameliorates climate change and ultimately increases global warming. A 2007 assessment by the Intergovernmental Panel $/$ on Climate Change (IPCC) estimated that 17 percent of annual carbon-dioxide emission comes from deforestation.

Another aspect is the use of cement that accounts for around 5 percent of global carbon-dioxide emissions. Cement is the primary ingredient in concrete which is needed for construction buildings, roads, and bridges. The production of cement releases greenhouse gas emissions both directly and indirectly that is heating of limestone release carbon-dioxide directly while the burning of fossil fuels to heat the kiln (furnace for burning pottery, bricks, lime) indirectly results in carbon-dioxide emissions.

The third aspect is the emission associated with increased consumption of an outcome of development. For example, more highways will discourage the use of public transit, resulting in more emission (Paul Chan, How does development affect the environment). Sometimes we have seen that there are many factors that affect economic development. Three important ones include population, conflict and environment. Effect of population growth can be positive or negative depending on the circumstances. One of the biggest impacts on economic development is the geographic features of the environment. When we analysed about the cause of development on environment it is economic sector that had been impacted.

\section{G. Social and Cultural Marginalisation of Tribal:}

Culture and identity of the tribal people is one of the main impacts of dam construction in the country. There several major tribes in Assam these tribes have their distinct identity, language, customs and location. As the total population of the tribal is small in number but are excessively vulnerable to the influx of outsiders that is likely to take place with the construction of huge infrastructure projects. Take the case of Subansiri project the tribal people of Arunachal Pradesh mainly from the Siberite and Gengi villages had to migrate in the other parts of the land. The newly resettled people will marginalised from the other native people. Because the displaced people face serious problems in terms of livelihood, shelter, location, occupation, ways of living, their cultural performance etc. Mishing is the major tribe in the downstream of Subansiri Project. The Mishing people are scare of natural calamities like earthquake, floods, etc. However, one can get a distinct sense of outsiders coming in and alienating the locals in their own land. At Gerukamukh, the office of the NHPC for the Subansiri dam site are surrounded by a high wall fence topped with barbed wires. Locals said that such walls surrounded their area it has been taken over by the company without any compensation to them. It is significant to know that the Mishing, Apatani, Karbi, etc. tribes have been identified as one of the endangered languages and locations of the world by the UNESCO as a part of its Endangered Languages Programme (ELP). Like Idu, the Mishing community's tradition, custom, faith and beliefs are greatly attached to the river Subansiri. The construction of dam will herald the end of our culture and tradition as the river Subansiri as well as Dibang is as sacred to us as is the river Ganga to the Hindus. We believe that after death the Idu-Mishmi and the Mishing ( $1^{\text {st }}$ Order Priest) Sineru carries forward our souls through these rivers. The Hills, the rivers and the mountains are deeply embedded in our ethos. It is the life force of our community. Destruction or endangerment of these will be a threat to the communities itself. Development at the cost of culture and tradition is not acceptable to us. 
On the other hand, Dam development at Kopili and Karbi Langpi rivers in West Karbi Anglong district of Assam had affected the indigenous peoples of flora and fauna. Forest products have been collected by the Karbi's people for the purpose of religious practices has been consumed since from the time immemorial. The Karbi's religious practices need such plant species which will not found easily from the project areas such species would be extinct. The Karbi culture is mainly associated with the forest resources. Meanwhile, some of the people who are belief in the western or modern culture and religion may also take an advantage. It is pertinent to remark that when the indigenous culture and religion is lost in the name of development project benefitted by the others such indigenous identity is automatically will lose forever. The government has no responsible for the lost of the indigenous culture unless the indigenous people are not aware from pollution and damage or extinct. And government should never try to do because extinction of the indigenous people means extinction of the cultural heritage and it is not possible to consider that India, a multicultural society. But in India, project development is prevalent in the rich forest area as well as in the tribal dominant area which has been exploited and discriminated for them. Right to equality and right to religion of fundamental rights of the Indian constitution are meaningless it is only structure in the constitution of India.

\section{CONCLUSION}

Being a geologically and seismically sensitive region, comprehensive environmental risk assessment assumes great significance in the Northeast to decide the viability of mega dams in the region. These environmental risks need to be properly understood while evaluating the viability of dams in the Northeast and Assam in particular. One of the most serious impacts of the dam on Subansiri River is due to the ecological degradation suffered by the river and the riparian land in downstream areas. There is another issue and concern in the mind of the people. Therefore, while taking decision on large dams within Indian land these factors must be considered that the native people do not feel deprivation and stagnation from the development initiatives. Therefore, the then Prime Minister of India, Jawaharlal Nehru said "dam is the temples of modern India". Dam reduces the frequency of floods from occurring and it control flood. However, the expert committee recommended that undoubtedly there could be some environmental impact of flora and fauna due to fluctuation. Some adverse effects need a remedy by maintaining a minimum flow during off-peak period and when the Power House is operated in peaking mode that such release for maintaining ecology and maintenance of river flow farther downstream was not seemingly dealt with by Environmental Advisory Committee (EAC) but is now dealt with. Actually dam may provide safety to the downstream areas from landslides and floods while such control of water release as and when artificial dam caused by a landslide gives way. If any initial happen of land-slides are noticed their strengthening should be carried out, if possible as an ample safety measure. The World Commission on Dam has recommended a practical and fair path to follow it. It is now the turn of governments, developers and financiers to implement and comply with the WCD and expert recommendations which would possible to conserve freshwater habitats and species of future generations. Sometime, but damaging the folklore source and destruction of environment affects the cultural diversity of the region. Due to the dam construction the tribal religious or cultural flora and fauna has been caused as well as affected. Tribal (Karbi) the earliest settler of Assam which concern from Kopili and Langpi dam construction has destroy or harm the socio-cultural flora and fauna.

\section{BIBLIOGRAPHY}

1. Jatana, B.L., (1999) Fail-Safe Large Dams in Earthquake Prone Himalayan Region, ISET Journal of Earthquake Technology, Paper No. 387, Vol. 36, No. 1, March, www.home.iik.ac.in. Accessed date on $23^{\text {rd }}$ March 2017.

2. Dutta \& Sarma (2012) Lower Subansiri Hydroelectric Power Project and Future of the Subansiri River Ecosystem, www.iitd.ac.in/../eia_casestudy1.Date. Accessed date on 26th March 2017.

3. Taher \& Ahmed (1998) Geography of North-East India, published by Mani Manik Prakash Panbazar, Guwahati.

4. www. Forest.bih.nic.in.

5. Euromodel - 'Environment and Development', www.projekty.osu.cz. Accessed date on $7^{\text {th }}$ March 2018.

6. Paul Chan, 'How does Development Affect the Environment', https://www.quora.com. Accessed date on $7^{\text {th }}$ March 2018. 
International Journal of Trend in Scientific Research and Development (IJTSRD) ISSN: 2456-6470

7. Vulli Dhanaraju (2016) A Textbook of Environmental History of India, published by dominant, Daryaganj, N. Delhi. Accessed date on $25^{\text {th }}$ March 2017.

8. Nayak A. K., (2016) Dams and Development in India, Rawat publications, Jaipur, India. Accessed date on $25^{\text {th }}$ March 2017.

9. Das Kr. Pranab, (2013) North-East, 'The Power House of India': Prospects and Problems, IOSR Journal of Humanities And Social Science (IOSRJHSS) Volume 18, Issue 3 (Nov. - Dec.), PP 3648 e-ISSN: 2279-0837, p-ISSN: 2279-0845. www.iosrjournals.org www.iosrjournals.org. Accessed date on $26^{\text {th }}$ March 2017.

10. Saikia, Hemata (2012) Political Economy of big Dam in North East India, Basic Research Journal of Social and Political Sciences Vol. 1 (1), http//www.basicresearchjournals.org. Accessed date on $26^{\text {th }}$ March 2017.

11. Devi \& Goswami (2014) The Subansiri River basin in Eastern Himalayas and the Alaknanda
River Basin in Western Himalayas: A Comprehensive study in regard to their Geoenvironment and Hydrometeorology, Vol. 5, No. 1, www.ipublishing.co.in/ijesarticles/fourteen/. Accessed date on $23^{\text {rd }}$ March 2017.

12. Mega Dams: Campaigning against the plans of the Indian Government, https://www.opendemocracy.net. Accessed date on $23^{\text {rd }}$ March 2017.

13. Subansiri Lower Dam, https://en.m.wikipedia.org/wiki/Lower_Subansiri Dam. 8th April 2017

14. Lower Kopili HEP: outstanding issues that must be resolved before EAC can consider the project, https://sandrp.wordpress.com/2013/09/21/eacmust-address-issues-first-before-clearing-lowerkopili-hep/ Accessed date on $8^{\text {th }}$ April 2017.

15. Karbi Langpi dam posing threat to public, (http://www.assamtribune.com/scripts/) Accessed date on $9^{\text {th }}$ April 2017. 